\title{
An iterative method for solving multiple-set split feasibility problems in Banach spaces
}

\section{S. Al-HOMIDAN ${ }^{1}$, B. ALI ${ }^{2}$ and Y. I. SULEIMAN ${ }^{3}$}

\begin{abstract}
.
In this paper, we study generalized multiple-set split feasibility problems (in short, GMSSFP) in the frame work of p-uniformly convex real Banach spaces which are also uniformly smooth. We construct an iterative algorithm which is free from an operator norm and prove its strong convergence to a solution of GMSSFP, that is, a solution of convex problem and a common fixed point of a countable family of Bregman asymptotically quasi-nonexpansive mappings without requirement for semi-compactness on the mappings. We illustrate our algorithm and convergence result by a numerical example.
\end{abstract}

Acknowledgements. All authors contributed equally and significantly in writing this paper. The authors declare that they have no competing interests. All authors read and approved the final manuscript. First author ia grateful to King Fahd University of Petroleum and Minerals, Dhahran, Saudi Arabia for providing excellent research facilities to carry out this research work.

\section{REFERENCES}

[1] Alber, Y. I., Metric and generalized projection operators in Banach spaces: Properties and applications, in Theory and Applications of Nonlinear Operators of Accretive and Monotone Type (A. G. Kartsatos, Ed.), Lecture Notes in Pure and Appl. Math., 178, Marcel Dekker, New York, (1996), 15-50

[2] Al-Homidan, S., Ali, B. and Suleiman, Y. I., Generalized split equilibrium problems for countable family of relatively quasi-nonexpansive mappings, J. Nonlinear Convex Anal., 19 (2018), No. 7, 1109-1126

[3] Ansari, Q. H. and Rehan, A., Split feasibility and fixed point problems, in Nonlinear Analysis: Approximation Theory, Optimization and Applications, (Q. H. Ansari, Ed.), Birkhäuser, Springer, New Delhi, Heidelberg, New York, London, (2014), 231-280

[4] Ansari, Q. H. and Rehan, A., Iterative methods for generalized split feasibility problems in Banach spaces, Carpathian J. Math., 33 (2017), No. 1, 9-26

[5] Ansari, Q. H., Rehan, A. and Wen, C. F., Split hierarchical variational inequality problems and fixed point problems, J. Inequalit. Appl., (2015), Article ID 793

[6] Ansari, Q. H., Rehan, A. and Wen, C. F., Implicit and explicit algorithms for split common fixed point problems, J. Nonlinear Convex Anal., 17 (2016), No. 7, 1381-1397

[7] Ansari, Q. H., Rehan, A. and Yao, J. C., Split feasibility and fixed point problems for asymptotically $k$-strict pseudo-contractive mappings in intermediate sense, Fixed Point Theory, 18 (2017), No. 1, 57-68

[8] Bregman, L. M., The relaxation method for finding the common point of convex sets and its application to the solution of problems in convex programming, USSR Comput. Math. Math. Phys., 7 (1967), 200-217

[9] Byrne, C., Censor, Y., Gibali, A. and Reich, S., Weak and Strong convergence of algorithms for the split common null Point Problem, J. Convex Nonlinear Anal., 13 (2012), 759-775

Received: 21.11.2018; In revised form: 29.07.2019; Accepted: 05.08.2019

2010 Mathematics Subject Classification. 49J40, 49J52, 47J20.

Key words and phrases. Generalized multiple-set split feasibility problems, iterative methods, Bregman asymptotically quasi-nonexpansive mappings, uniformly smooth Banach spaces.

Corresponding author: S. Al-Homidan; homidan@kfupm.edu.sa 
[10] Censor, Y. and Elfving, T., A multiprojection algorithm using Bregman projection in a product space, Numer. Algor., 8 (1994), 221-239

[11] Censor, Y., Elfving, T., Kopf, N. and Bortfed, T., The multiple-set split feasibility problem and its applications for inverse problems, Inverse Problems, 21 (2005), 2071-2084

[12] Chang, S. S., Cho, Y. J., Kim, J. K., Zhang, W. B. and Yang, L., Multiple-set split feasibility problems for asymptotically strict pseudocontractions, Abstr. Appl. Anal., (2012), Article ID 491760

[13] Chang, S. S., Cho, Y. J. and Zhou, H., Demiclosed principal and week convergence problems for asymptotically nonexpansive mappings, J. Korean Math. Soc., 38 (2001), 1245-1260

[14] Chang, S. S., Wang, L., Wang, X. R. and Chan, C. K., Strong convergence theorems for Bregman totally quasiasymptotically nonexpansive mappings in reflexive Banach spaces, Appl. Math. Comput., 228 (2014), 38-46

[15] Chidume, C. E., Geometric Properties of Banach Spaces and Nonlinear Iterations, Springer-Verlag, London (2009)

[16] Giang, D. M., Strodiot, J. J. and Nguyen, V. H., Strong convergence of an iterative method for solving the multiple set split equality fixed point problem in a real Hilbert space, Rev. R. Acad. Cienc. Exactas Fis. Nat. Ser. A Mat. RACSAM, 111 (2017), No. 4, 983-998

[17] Mainge, P. E., Strong convergence of projected subgradient methods for nonsmooth and nonstrictly convex minimization, Set Valued Anal., 16 (2008), 899-912

[18] Moudafi, A., A note on the split common fixed point problem for quasi-nonexpansive operators, Nonlinear Anal., 74 (2011), 4083-4087

[19] Naraghirad, E., Yao, J. C., Bregman weak relatively nonexpansive map- pings in Banach spaces, Fixed Point Theory and Applications 2013 (2013), Article ID 21

[20] Qin, L. J., Wang, L. and Chang, S. S., Multiple-sets split split feasibility problem for a finite family of asymptotically quasi-nonexpansive mappings, PanAmerican Math. J., 22 (2012), 37-45

[21] Reich, S. and Sabach, S., Two strong convergence theorems for a proximal method in reflexive Banach spaces, Numer. Funct. Anal. Optim., 31 (2010), 22-44

[22] Wang, S. and Kang, S. M., Strong convergence iterative algorithms for equilibrium problems and fixed point problems in Banach spaces, Abstr. Appl. Anal., (2013), ID No. 619762

[23] Wu, Y., Cheng, R. and Shi, L. Y., Split equality problem and multiple-set split equality problem for quasinonexpansive multivalued mappings, J. Inequal. Appl., (2014), Article ID 428

[24] Xu, H.-K., An iterative approach to quadratic optimization, J. Optim. Theory Appl., 116 (2003), 659-678

[25] Xu, Z. B. and Roach, G. F., Characteristic inequalities of uniformly smooth Banach spaces, J. Math. Anal. Appl., 157 (1991), 189-210

[26] Takahashi, W., Introduction to Nonlinear and Convex Analysis, Yokohama Publishers, Yokohama (2009)

[27] Zhao, J. and Wang, S., Mixed iteartive algorithms for the multiple-set split equality common fixed point problems without prior knowledge of operator norms, Optimization, 65 (2015), 1069-1083

${ }^{1}$ Department of MATHEMATics AND Statistics

King Fahd University of Petroleum \& Minerals

DHAHRAN, SAUDi ARABIA

Email address: homidan@kfupm.edu.sa

${ }^{2}$ Department of Mathematical Sciences

BAYERO UNIVERSITY, KANO

KANO, NIGERIA

Email address: bashiralik@yahoo.com

${ }^{3}$ Department of Mathematics

KANO UNIVERSITY OF SCIENCE AND TECHNOLOGY

P. M. B. 3042, WUdil, KANO, NigERIA

Email address: yubrameyahoo.com 